Editorial Manager(tm) for Vocations and Learning: Studies in vocational and

professional education

Manuscript Draft

Manuscript Number: VOCA62

Title: 'KNOWLEDGE WORKERS' AS THE NEW APPRENTICES: THE INFLUENCE OF ORGANISATIONAL AUTONOMY, GOALS AND VALUES ON THE NURTURING OF EXPERTISE

Article Type: Article of theoretical or empirical imp.

Keywords: apprenticeship; knowledge workers; software engineering; university contract researchers; expertise; trust; workforce development; workplace learning; expansive - restrictive framework

Corresponding Author: Professor Alison Fuller,

Corresponding Author's Institution: University of Southampton

First Author: Alison Fuller

Order of Authors: Alison Fuller; Lorna Unwin

Abstract: This paper explores the concept of apprenticeship in the context of the professional formation of knowledge workers. It draws on evidence from research conducted in two knowledge intensive organizations: a research-intensive, elite university; and a 'cutting edge' software engineering company. In the former, we investigated the learning environments of contract researchers, whilst in the latter, we focused on the learning environments of software engineers. Both organisations have 'global' reach in that they operate within international marketplaces and see themselves as international players. The paper asks to what extent the important role of maturation with regard to the formation of expertise is being undermined by the pressurised nature of contemporary workplaces (in both the public and private sectors). It argues that conceiving the professional formation of knowledge workers as apprenticeship provides a way forward to improve the way employers construct and support that formation. 


\section{'KNOWLEDGE WORKERS' AS THE NEW APPRENTICES: THE INFLUENCE OF ORGANISATIONAL AUTONOMY, GOALS AND VALUES ON THE NURTURING OF EXPERTISE}

\section{Introduction}

Apprenticeship is a model of learning that has relevance across the vocationalprofessional spectrum of occupations. The learning journey (from novice to expert) that underpins apprenticeship is followed by surgeons, musicians, journalists and lawyers as well as by hairdressers, plumbers and chefs. In terms of the professional formation of socalled knowledge workers, their apprenticeship may start during their university degree; for example, medical students will spend time working in hospitals, and engineers may spend a year out on work placement. For others, particularly in the areas of media and design, their formation journey might include a period of internships.

Once employed, the experience of apprentice knowledge workers will reflect the occupational and organisational context in which they work. For some, notably doctors or stone masons, the apprenticeship will extend over many years, whilst for others notably in the service sectors, the pressure to become productive workers will restrict the scope and nature of the apprenticeship. Given that one of the tenets of professional status is that the individual has considerable discretion over their work, it could be argued that the learning journey for the apprentice knowledge worker extends beyond the traditional point when the apprentice has been certified as mastering the body of knowledge and skills required to do the job. A key question would be: when would knowledge workers be deemed to have reached the end of their apprenticeship? 
This paper explores the concept of apprenticeship in the context of the professional formation of knowledge workers. It draws on evidence from research conducted in two knowledge intensive organisations: a research-led university (The University) and a cutting edge software engineering company (The Company). ${ }^{1}$ In the former, we investigated the learning environments of contract researchers; in the latter, we focused on the learning environments of software engineers. The paper argues that conceiving the professional formation of knowledge workers as apprenticeship provides an opportunity to improve the way employers, professional bodies, and educational and training institutions construct and support that formation. In addition, the paper asks to what extent the important role of maturation and socialisation with regard to the formation of expertise is being undermined by the pressurised nature of contemporary work places (in both the public and private sectors) and by the continued emphasis on a front-loaded model of education and training.

The paper is organised in four sections. In the following two sections we discuss the concept of the knowledge worker and then provide some background to the case studies and describe how we collected the research evidence. The third section presents our analysis of the researchers and software engineers as apprentices and draws on evidence from the case studies to explore three themes derived from the expansive restrictive framework (Fuller and Unwin 2004): organisational goals and workforce development; valuing expertise and trust; and, opportunities to expand learning. The research evidence is used to illustrate differences in the workplace environments

\footnotetext{
${ }^{1}$ The research was carried out within a project funded by the UK's Economic and Social Research Council (ESRC), 'Learning as Work: Teaching and Learning Process in the Contemporary Work Organisation' (Grant number: RES-139-25-0110).
} 
experienced by the two groups of knowledge workers. The paper ends by drawing some conclusions about the ways in which the 'apprenticeships' of university researchers and software engineers are constructed and supported within the two organisations.

\section{The Concept of the Knowledge Worker}

It is important to recognize that the concepts of knowledge work and knowledge workers (as well as knowledge economy and society) are hotly contested terms. Like others, we reject the idea that conclusions about knowledge and skills can be easily read off from job titles or levels of qualifications (see, for example, Livingstone and Sawchuk 2003; Fenwick 2004; Fuller et al. 2007, Felstead et al, 2009). In this regard, we are sympathetic to the critique made by Brint (2001) of the term 'knowledge workers', which he sees as being used increasingly as a badge conferring prestige rather than an accurate description of the work people do.

The origin of the concept of knowledge work, usually attributed to the management theorist Peter Drucker (1959 and 1969, see also Reich 1991), took its defining characteristic to be the creation of information, ideas and concepts which add value. 'Knowledge work' was seen to be the mechanism by which knowledge was transformed into something (a commodity) that could be exchanged. Such work and workers were not new, but were growing as a result of the changing industrial, economic and technological landscape (Cortada 1998). The work of Daniel Bell (1973) has made a distinctive contribution to the debate. He argued that the important characteristic of knowledge work was the source of knowledge on which it relied. According to Bell, it 
was the application and utilisation of theoretical, scientific knowledge that was the distinguishing feature of knowledge work (Guile 2006). At the time when Bell was writing, the labour market demand for scientific, technical and professional staff was growing in industrialised economies, and their education systems were expanding to increase the supply of graduates with the required level of academic knowledge. The logic underpinning Bell's analysis persists and continues to provide an important policy rationale for the continuing expansion of HE systems and creation of a more highly qualified workforce in countries such as the UK.

There is clearly a debate about the way in which many jobs now require high level qualifications for entry including those that previously were not classed as graduate jobs (Wolf, 2002; Brown and Hesketh 2004; Brown et al 2008). This debate focuses on qualifications as a signalling device used particularly by multi-national companies in their recruitment processes, but does not discuss the professional formation of those selected, or the connection between their qualifications and the expertise required to do their jobs. This paper aims, therefore to widen the dimensions of discussions about the graduate labour market.

The individuals discussed in this paper can be categorised as knowledge workers because creating and producing new knowledge is an expected outcome of their work, even though the purposes for which it is generated differ. Both the software engineers and the university researchers are expected to have a solid theoretical and scientific background gained through their achievement of a Batchelor's Degree. For the software 
engineers, the possession of a good degree (first or high upper second) is a minimum requirement for employment in the software engineering organization, whilst university researchers are also expected to have a post-graduate qualification. Our case study organizations also accord with Alvesson's description of knowledge-intensive companies (or organizations) as ones in which: 'most work is said to be of an intellectual nature and where well-educated, qualified employees form the major part of the workforce' (Alvesson 2001: 863). As such, the university researchers and software engineers conform to the current homogenizing narrative about the nature of knowledge workers. However, when we examine the formation journeys of these two sets of workers through the lens of apprenticeship, stark differences emerge.

\section{The Case Studies: Background and Data Collection}

The context of these two organisations is clearly very different, as is their size. The University has several thousand employees compared with The Company's approximately 350 staff. The Company is privately owned by an Employee Benefit Trust. The University is largely publicly funded and has to behave in prescribed ways in order to receive its core funding for teaching and research. Given its ownership structure, The Company, is in a position to act autonomously, make its own decisions about priorities and goals. It experiences relatively little 'interference' from external sources with regard to how it conceives and runs its business beyond the need to comply with relevant laws regulating employment, health and safety, data protection and so on. This relative freedom is certainly not shared by The University. Like other universities in the UK, this university is governed by a Royal Charter (administered by the Privy Council) and so is 
technically an independent institution. However, since the 1980s and, in particular, since the 2004 Higher Education Act, universities have become subject to more intense monitoring and accountability regimes exercised by central government and its agencies. Its activities are, then, subject to a range of significant external influences. Elsewhere we have described and compared these two organisations in terms of their very different 'productive systems' (see Felstead et al, 2009).

With regards to the two sets of knowledge workers that are the focus of this paper, there are important contrasts in their terms and conditions of employment. The University’s complex managerial structures are extended and hierarchical. Contract researchers (CRs) are at the bottom of tiers of institutional relationships that include established academic staff such as principal investigators, lecturers, department and faculty heads, and senior university level management. Unlike established staff, contract researchers are paid out of 'earned income' gained from successful bidding for externally funded research. Traditionally, they have been employed on fixed term contracts attached to the lifespan of particular projects. Following the introduction of European legislation in 2006 to reduce the use of fixed term contracts, universities have responded by creating new 'open-ended' contracts, which whilst they avoid linking an individual researcher with a specific fixed-term project, still do not protect the researcher from being made redundant if appropriate work, for example in another department, cannot be found for them. Hence, research staff experience much less security of employment than 'established staff', whose salaries are paid out of public funds. In the case of the university participating in this research, substantial efforts had been made to improve the 
terms and conditions of contract researchers. As a research-intensive university, it is concerned that lack of job security contributes to high turnover of research staff in this area and the loss of individuals with highly developed skills and expertise.

In contrast, The Company employs around 200 (mainly male) software engineers on permanent contracts of employment. In addition to their salaries, all employees received an annual share of profit, based on their performance. Staff turnover is very low (around 5\%) and one third of employees have been with the company for over 10 years. The Company has maintained the original principles on which it was founded, namely to create a business that combined the desire for a collegial working environment that allowed for personal and collective growth coupled with ambitious goals for business success. At the heart of the enterprise is a management structure that places trust in employees; a trust based on a belief in their expertise and, fundamentally, in the robust business framework in which products and services are created.

\section{Data collection}

In The University, our research was conducted in two stages. First, a series of face-toface key informant interviews were undertaken with senior HR, personnel and staff development managers as well as with the Deans in three faculties spanning the biological, experimental and social sciences. The purpose of these interviews was to obtain contextual information and to gain an institutional perspective on how recent contractual changes affecting researchers (stemming from the implementation of European legislation) were being perceived and implemented. The second stage of the 
research involved interviews with staff at department level and with Heads of Department, principal investigators (PIs) and contract researchers (CRs) of different levels of seniority and experience, and with a mix of males and females. This allowed us to collect the views of respondents located at different levels within the institutional hierarchy. A total of 54 interviews were carried out across the two data gathering stages.

In The Company, interviews were conducted with 26 members of staff, including the chairman, directors, a sample of software engineers (including two females), staff from Human Resources (HR) and employees in other departments. In addition, nonparticipant observation was conducted at the head office, focusing on everyday work activities, and at a 24-hour recruitment event to select new software engineers. The latter enabled us to compare the way in which potential recruits conceptualized their personal identities as software workers with those of existing employees, and to listen to the corporate narrative fed to interview candidates over a 24-hour period. It also revealed the very high value that managers placed on technical competence, to the extent that they were prepared to recruit candidates whose communication skills were poor, and even those who were not particularly innovative or adventurous thinkers. This complemented the insights we were able to gather from the interviews we carried out at a variety of levels with the organization. 


\section{University Researchers and Software Engineers as Apprentices}

Both the software engineers and university researchers share a similar level of educational attainment and have entered knowledge intensive environments. As knowledge worker apprentices, however, our evidence will show the nature of their formation is very different. We will use elements of the expansive - restrictive framework (Fuller and Unwin 2003, 2004, 2008) to explore the differences in the characteristics of the two workplaces as learning environments. As our two groups of workers are based within discernable communities of practice, Lave and Wenger's (1991) concept of legitimate peripheral participation is relevant. Both the researchers and the engineers are engaged as 'legitimate peripheral participants' in a journey within the confines of their communities. For the purposes of this paper, we have grouped some of the expansive - restrictive characteristics of workplaces as learning environments into three themes. Evidence from the two organisations is used to illustrate these and to indicate key differences and contrasts. 
Organisational goals and workforce development

\begin{tabular}{|l|l|}
\hline \multicolumn{1}{|c|}{ Expansive } & \multicolumn{1}{c|}{ Restrictive } \\
\hline $\begin{array}{l}\text { Workforce development used as vehicle } \\
\text { for aligning goals of the organisation } \\
\text { and of the individual }\end{array}$ & $\begin{array}{l}\text { Workforce development used only to tailor } \\
\text { individual capability to organisational goals }\end{array}$ \\
\hline $\begin{array}{l}\text { Recognition of and support for workers } \\
\text { as learners - newcomers (including } \\
\text { trainees) given time to become full } \\
\text { members of the community; Vision of } \\
\text { workplace learning - career progression }\end{array}$ & $\begin{array}{l}\text { Workers only seen as productive units - fast } \\
\text { transition from newcomer/trainee to fully } \\
\text { productive worker; Short-termism - get the job } \\
\text { done }\end{array}$ \\
\hline $\begin{array}{l}\text { Managers given time to support } \\
\text { workforce development and facilitate } \\
\text { workplace learning }\end{array}$ & $\begin{array}{l}\text { Managers restricted to controlling workforce and } \\
\text { meeting targets }\end{array}$ \\
\hline
\end{tabular}

We examine the theme in light of the associated expansive and restrictive features in relation to the university researchers and then to the software engineers.

\section{University contract researchers}

The negative effects of contract research in the UK have been well documented (see inter alia Williams et al, 1974; Bryson \& Tulle-Winton, 1994; Freedman et al, 2000; Roberts, 2002; Allen-Collinson, 2003) and include job insecurity, an inferior 'second class' status compared to academic staff on permanent contracts, and a lack of a coherent career and development structure. These negative effects and their implications, for Higher Education Institutions (HEIs) as well as CRs, has resulted in several policy initiatives (CVCP1996; OST 1997). These initiatives aimed to set out a framework for the better management of CRs. The main focus was on workforce development to address issues of recruitment and retention, training and career progression. 
Our case study university was increasing its commitment to improving the working conditions of CRs and enhancing their career prospects in response to these national policy initiatives and the introduction of the new European legislation. It also related to growing recognition of the contribution CRs were making to the university's organisational goals and the adverse effects of research staff turnover. Our evidence suggests that members of the university's Human Resources (HR) and Personnel department were questioning how the treatment, skill formation and career development of CRs could be improved to the benefit of individuals and the organisation:

...if we can get it right then we will be able to both attract and retain very good people which is just absolutely critical to the future of the institution...however, brilliant the PI [Principal Investigator] is, they need to be surrounded by really really good researchers because actually it's the dynamic of all that that works... (HR Director)

The university had introduced new staff development and training, and careers guidance policies and provision to support CRs. Whilst, this activity and investment was generally well-received by individual researchers, it was not so clear how well it was helping to realise the HR Director's vision of aligning workforce development with organisational goals. This was because the training and careers advice were experienced primarily as resources for helping researchers to get other jobs, often elsewhere, if funding became unavailable to support their employment. As this researcher observes:

I think the careers advice here is very good and they do seem to have a whole section to help geared to help contract research staff find new jobs and new employment, which I think is incredible considering that they're going to be leaving the organization... (Research Assistant, RA)

There are two important points to note from this. First, training and careers advice are experienced as resources which help individual researchers to make the transition to alternative employment. Second, the location of careers advice and training in separate and distinct structures from the departments and teams in which researchers work, reinforces the perception that the alignment between organisational goals and the development of this sub-group of the university's workforce remains weak. This is 
further evidenced through the continuing existence of 'master - servant' style relationships between (at least some) PIs and their researchers. Where PIs conceptualise and perceive researchers as providing the human resources to carry out their instructions about how to 'execute' project tasks, they view the individual's capabilities solely in terms of how they can be tailored to best achieve their (the PIs') goals:

I can think of one department where the researcher just has to do the work: [the supervisor asks], "what do you mean look at their future career?" "What do you mean give them time to go to a workshop?...Well that's crazy who's going to do the project?" You know it's almost a factory mentality. (Personnel Officer)

For this department, then, the researchers are seen as productive workers whose task is to 'get the job' done. In the cited example, management is conceived as controlling the behaviour of the researchers to ensure that the PI's goals are met. This narrowly conceived idea of management is likely to be just one among several competing views in a large and complex institution, where there are corporate, sub-group (e.g departmental or research group) and individual interests at play. According to the Personnel Manager, such tensions can adversely affect the attainment of strategic organisational and workforce development goals.

Although PIs are in the key line management position vis-à-vis their CRs, there is no universal and explicit expectation that they will take responsibility for their researchers' professional formation and career development. Indeed, there are features of the career building process in research which militate against PIs 'promoting' their staff. For example, there are norms about who can be named as PI or even be a co-applicant on research council grant applications, which often restrict this opportunity to those who have permanent academic contracts. It also demonstrates the plurality of goals 
(individual, research group, departmental, institutional) that exist in The University and the potential this generates for tension and conflict as well as creative alignment when interests happen to coincide. The culturally and structurally privileged position of PIs in the institution means that they have considerable autonomy over the conception of their research projects and management of their teams. This freedom can, of course, produce a diverse range of outcomes and experiences from the highly positive to the highly negative.

\section{Software engineers}

Perhaps The Company's most striking characteristic is its understanding of how to create the optimum conditions in which the different identities of its employees can be nurtured so that they are enabled to demonstrate and use their talents for the benefit of both themselves and the business.

As a labour process, software engineering has been described in terms of conforming to either a 'formalist' or a 'pragmatist' paradigm (Quintas 1994; see also Marks and Lockyer (2005). The formalist paradigm locates software development within the discipline of engineering where product development follows set procedures and stages. From this perspective, software development is positioned as an 'ad hoc process of "hacking" (i.e. writing code without rigorous planning and then hacking at it to remove bugs and achieve results)' (Barrett 2001: 26). Robinson et al. (1998) argue that a more pluralist approach is now required as software engineers need to work in teams of 
'equals' rather than in hierarchical systems of the past in which lead designers and system architects passed down their instructions to subordinates.

The Company demonstrates a commitment to planning, and the associated rigour of systematic quality assurance procedures that are in line with the 'formalist' tradition, and, importantly, the developers are called 'engineers'. The way work is organised (in self-managed teams), however, also reflects the pluralist approach and, at the same time, the artistry of development is celebrated through the secondment of engineers to a 'blue skies' team which develops new product ideas.

The two key organising principles in The Company are the self-managed team and the development of expertise through the everyday production process. For each new project, an architectural plan is devised. This is given to a nominated team which then breaks the plan down into smaller units. Through this process of problem solving and production planning, team members develop their expertise. Engineers work on projects that run, on average, for 6-12 months, though, occasionally, a team might exist for more than one project. This rotation is regarded as key to the facilitation of innovation and, due to the routine nature of parts of the production process, it is also used to limit the potential for engineers to become bored. Interaction between colleagues is aided by the physical and social environment. On each floor of the company's main building, there is a well-stocked kitchen, and there is a large subsidised restaurant. Shower rooms are also provided to enable staff to play sport at lunchtime or before and after work. Each section of the company is given a budget to pay for social events and, each year all staff and their 
partners are invited to participate in an overseas holiday and a garden party at the chairman's home.

The architectural planning of each project generates a set of benchmarks which form the basis of the company's performance review process and a workplace curriculum. This curriculum is made visible through a series of 'public folders' on the company's intranet to which all engineers are encouraged to contribute. The review process takes the form on an interview with an immediate supervisor who prepares a written report which is passed up to a line manager and then ultimately to the chairman and directors. The review determines the amount the employee will receive as a bonus and their share of the company's annual profit.

New employees, who spend the first 50 days after recruitment being closely supervised so that they learn on-the-job, are reviewed every three months for the first year and then every six months. At the heart of the review process is the company's concept that management is a form of 'teaching' and is, therefore, a key vehicle in a distributed approach to learning. Every member of staff is expected to have some managerial responsibility after their first year. Hence, an engineer will be assigned a new recruit to manage, eventually building up to becoming a team leader. The following comment illustrates the way in which 'teaching' on-the-job helps new recruits to be quickly integrated into the work process by being immersed in real tasks:

So I was given to a guy who was an experienced techie and someone who had management aspirations ... And I worked with him on supporting a major customer. Actually, I think it gave me a very good start in the company because it put me immediately in a position where I was very much in the deep end. Because 
I didn't really know the ropes and I had all this incredibly obscure and difficult code to support. And I had one guy who was a clear expert to guide me through it .... that kind of environment meant that I had to learn to stand on my own two feet quite quickly. (Software Engineer)

Once established, a manager is expected to spend the majority of their time supporting the development of their team members. This means that workforce development is explicitly fore-grounded and integrated within the work process, rather than being seen as something that is external to everyday workplace activity.

\section{Valuing of Trust and Expertise}

Understanding the nature of institutional trust relations is central to making sense of how expertise is valued. More than thirty years ago, Fox (1974) drew attention to the role of trust in employment relations and the difficulty of creating high trust in contexts essentially characterised by unequal power relations. A key indicator of the level of trust between managers and employees, is the extent to which different groups have discretion over the conception and execution of their work tasks. The second set of characteristics, we explore relates to trust and expertise and how they are valued in the two cases.

\begin{tabular}{|l|l|}
\hline \multicolumn{1}{|c|}{ Expansive } & \multicolumn{1}{c|}{ Restrictive } \\
\hline $\begin{array}{l}\text { Skills widely distributed though } \\
\text { workplace - multi-dimensional concept } \\
\text { of expertise; valuing expertise, high } \\
\text { trust }\end{array}$ & $\begin{array}{l}\text { Polarised distribution of skills and status - } \\
\text { knowledge/expertise regarded as being confined } \\
\text { to key workers; low trust }\end{array}$ \\
\hline $\begin{array}{l}\text { Workers given discretion to make } \\
\text { judgements and contribute to decision- } \\
\text { making }\end{array}$ & $\begin{array}{l}\text { Discretion limited to key workers - no employee } \\
\text { involvement in workplace decisions }\end{array}$ \\
\hline
\end{tabular}




\section{University contract researchers}

In the case of the University, a major question for the CRs is whether and at what point in their 'careers' they are able to conceive and submit research proposals in their own name to funding bodies. The achievement of this status is symbolic of the transition to a high trust employment relation in that by allowing an individual to be a named applicant, the university is recognising their role in the conception of the ideas contained in the proposal and as an appropriate person to represent the University in this activity. As a CR on 'someone else's project', he or she is likely to be assigned tasks and have little discretion over how these are carried out:

Well because I'm contract staff...I have to do what I'm told. So in terms of research, well my boss specifically is very sort of hands-on...So it's a question of going to her and asking exactly what you're going to be doing in the experiment that day.... (RA)

In addition, funding bodies have a range of rules over who is eligible to be included as named applicants or PIs and which provides further evidence of the boundary that researchers have to cross to achieve the trust of the institution and to have their expertise formally recognised. This is not to say, of course, that high trust cannot exist on a personal level between PIs and their researchers. Our case study evidence reveals several examples of where trusting and nurturing relationships clearly exist. However, here we want to expose the underpinning structures which are indicative of the relatively low trust, low valuing of expertise model, which is at the heart of universities' employment relationship with contract researchers. One research assistant illustrates graphically 
where the locus of control lies and how this can translate into negative outcomes for individuals.

...So we're going to put this[proposal] in....I told my ex-boss about this, you know said, this guy wants me to be on it... and I was like well it's completely my project anyway...but he rang up my colleague in this other institution and said that if XXX [researcher's name] goes on that grant then I'm pulling the plug on this whole thing... So my name gets scrubbed off and his name got put on it...' (RA)

The following example also provides insight into the extent to which researchers' expertise is valued. Where it is not clear that funding will continue to be available to support a contract, a redundancy procedure is invoked to explore what other opportunities within the organisation there may be to maintain the individual's employment. The sentiments behind this effort reflect the need for higher education institutions to comply with new regulations applying to fixed term contracts and which are designed to minimise the likelihood of researchers being made redundant at the end of projects, as well as this University's changing approach to the management of CRs.

However, the way this process is experienced reveals a misunderstanding of the level and nature of researchers' expertise, and how their specialist knowledge and skills are central to their self and professional identities. The following extract from an interview with an RA is illustrative:

...they put your CV in a box a year or so before your contract's due to end and then they try and find you an alternative position within the department to avoid making you redundant... but it's difficult to do that because people that work in particular group obviously have particular specialities and it's, I mean skills are definitely transferable, but it's still going to take a lot of training up for some postdocs to shift from one lab to another... So it's really not as easy as kind of transferring from one lab to the other... it's nice to learn a brand new technique within your own field, but to go into somebody else's field completely unknown, that you've never worked on before at all, and then just effectively start from scratch again... (RA) 


\section{Software engineers}

The Company recruits engineers from a small number of research-intensive universities in the UK, with most coming from Oxford and Cambridge. Those chosen for interview will have demonstrated high levels of academic achievement at both school and university, and may already have some connection with the company through a work placement in their university vacations. The company stresses that it only seeks job applications from high achievers and this message is reinforced once new recruits start work. Throughout our interviews, software engineers often stressed that they had welcomed the chance to join an 'intelligent' community as the key reason for accepting a job. The following comment, from an engineer who joined the organization straight from university four years ago, illustrates the communal belief in the valuing of expertise:

The kind of people we have, this will sound arrogant and elitist, but they're sort of, a long way above the average you might encounter. If you go on a "how to program course", the people working on that course generally would be of a lot lower ability than the people here. (Software Engineer)

A key function of the belief that they are part of an 'intelligent' community appears to be that it helps the engineers cope with the pressure and stress of their interactions with the company's equally intelligent clients. As well as believing in their own expertise, the engineers know that if they struggle to find a way to solve a client's problem, they can seek advice from their peers and managers. The following comment from a recently employed engineer captures this sense of belief:

Well you've got to be clever enough technically to do it, to have a technical/problem-solving set of skills... I guess belief in one's own ability ... but I knew when I'd need help the help was there. (Software Engineer) 
New recruits can come from a range of disciplinary backgrounds stretching from computer science through to the arts and humanities, though non-science applicants usually have an A level in Mathematics. Whilst prior technical ability is not a requirement, as the company's intensive induction training builds the required skills, it is highly prized. During the 24-hour recruitment process, applicants are expected to show they have strong inter-personal skills and the ability to solve problems as part of a team. Interviews with the company's directors show that they believe that these skills are best developed in the workplace through collective engagement in work tasks and interaction with clients.

Although there is a hierarchy in terms of job levels within the company, horizontal movement is regarded as perfectly normal and desirable. A 'second line manager', for example, who was regarded as the best 'techie' in their team might stop managing for a time in order to concentrate on providing additional technical expertise. As one director explained:

You would never say you were, therefore, moving from priority level one to level two. I've got 73 people in my unit and I've got 72 grades in effect, because everyone is in a unique place. (Director) 
Opportunities to expand learning

\begin{tabular}{|l|l|}
\hline \multicolumn{1}{|c|}{ Expansive } & \multicolumn{1}{c|}{ Restrictive } \\
\hline $\begin{array}{l}\text { Participation in different communities of } \\
\text { practice is encouraged - job/team } \\
\text { boundaries can be crossed. }\end{array}$ & $\begin{array}{l}\text { Participation restricted to immediate work } \\
\text { team/area - boundary crossing discouraged }\end{array}$ \\
\hline $\begin{array}{l}\text { Planned time off-the-job for reflection } \\
\text { and deeper learning beyond immediate } \\
\text { job requirements }\end{array}$ & $\begin{array}{l}\text { All training on-the-job and limited to immediate } \\
\text { job requirements }\end{array}$ \\
\hline
\end{tabular}

University contract researchers

The University has expanded its training and careers guidance services and is actively encouraging researchers to take up the increasing opportunities to attend training courses and advice and guidance sessions that are now available. Whilst these services were welcomed by researchers as resources that could help them become more employable and get jobs elsewhere, it was less clear how beneficial they were in supporting an individual's career development and progression within the institution. Indeed, the evidence suggests that, particularly for researchers in the natural, experimental and biological sciences, researchers can improve their career prospects by gaining experience working in high profile research groups in their specialist field and which are likely to be located in a variety of institutions and countries. Here the onus appears to be on the individual researcher to manage their own skill formation and accrual of experience in a way that they can package to optimise their position in a highly competitive global labour market. This is revealed in the following quotation from a PI reflecting on how he has become a leader in his field.

I happen to think, like it or not, that mobility is important for academic development...the fact that my academic development was really helped by the fact 
that I worked in Strasbourg, Birmingham, Durham, here, you know, I learned skills. I learned about different ways of thinking about problems. (PI)

Such an approach conforms to the image of the knowledge worker as a highly desirable expert who can trade their skills in the marketplace and float free of organizational structures and loyalties. The University's treatment of CRs could be said to have fostered and even traded on that image. One implication of this is that, for researchers, the opportunities to expand learning lie in the individual's ability to access positions in a global research labour market and, thus, to increase their chances to learn from the leaders in their specialist field; rather than from the opportunities for learning made available within a single research group, department or university. Who benefits from this approach may well reveal uneven patterns of achievement according to social characteristics (e.g. age, gender, ethnicity, family status). As one PI commented: “...there's a lot of people who, for various reasons, aren’t able to be as mobile." Certainly, it was not uncommon, particularly, for the female researchers in our sample to comment on the difficulty of sustaining this model of skill formation and career progression into their early thirties. The lengthening time it was taking for researchers to make the transition to permanent positions following the attainment of their $\mathrm{PhDs}$ and a succession of post-doctoral appointments meant that for both males and females continuing insecurity into their early thirties was impacting on their ability 'to settle down and start their own families'.

Our evidence suggests that there are weaknesses in the ability of existing approaches and practices in The University to scaffold individuals beyond the last (post- 
doc) stage of their apprenticeship and into the role of autonomous researcher generating their own projects. Part of the problem is that there is a shortage of the sort of research posts that allow holders to make their own applications. However, there is also the question of whether PIs recognise that the ability to generate ideas and translate them into fundable research proposals is a skill that their researchers need support to develop. As one PI observed, helping people to make the transition from 'post-doc' is challenging: 'I must admit this has worried me increasingly and I think I'm now involving the research staff more in the generation of the proposals as well.'

\section{Software engineers}

The Company's approach to workforce development is strongly located within situated and socio-cultural theories of learning. A key tension in terms of the "expansiverestrictive' framework is the extent to which the company's approach to off-the-job training could be said to be restrictive in nature. Any employee who wanted to participate in an off-the-job learning opportunity would not be prevented, but the overwhelming ethos is that there is sufficient expertise located within the company itself and in its client community to enable workforce development to be a predominantly internal affair.

Some managers are concerned about whether this approach is still viable given the fact that the company is now expanding its quota of employees with a business development brief and one female manager also questioned the extent to which more exposure to external ideas would help to bring fresh thinking into the organisation. The performance review system and annual profit share arrangements clearly serve the need to reward performance in a visible and concrete manner. It also provides a powerful 
mechanism for engendering high levels of employee loyalty. To that extent, the company has the feel of an organisation that is both self-reverential and self-referential and our research data provided no evidence of worker resistance.

We have already noted that the physical environment was very conducive to employee interaction. In some ways, the working environment and the 'tutorial' style of the performance reviews could be said to mimic the atmosphere of an Oxbridge college, and hence, many of the new engineers would certainly feel immediately 'at home'. The company is also sensitive to work-life balance needs (see Scarborough and Swan 1999; Felstead et al. 2005). It had established an office in Scotland, despite the fact that the company has no Scottish clients, because, according to the head of the office, a small group of employees "were very happy to stay in the company, but basically could not settle in the South East of England". Employees are allowed to work flexible hours and encouraged to take sabbaticals to pursue their personal interests. This determination of the Directors to find ways to retain valued staff by enabling the creation of the new office is in stark contrast to The University's management of CRs.

Barrett (2005: 3-4) has cautioned against what she regards as the exaggerated claims that software workers are destined to become the 'future aristocrats of the labour market' because they have 'served to obscure much of what the people developing software actually do from day-to-day at work'. This was certainly reflected in The Company where engineers do spend a great deal of time applying their technical knowhow to a range of diagnostic activities such as writing thousands of lines of computer 
code, testing software systems and computer routines, and designing new software architecture for new products. They also had to demonstrate their technical intelligence on a daily basis with customers seeking updates and progress reports. For many, therefore, the label 'engineer' aptly described the reality of their occupational role and captured their professional identity. They were also working in a relatively stable and very successful commercial environment where employee turnover was low. In that sense, they conformed more to the Japanese model of the loyal company career professional, who progresses as an 'apprentice' through a highly structured internal labour market, than to the highly mobile, risk-taking 'knowledge worker' in the new economy. A company director explained this as follows:

We're talking about a lot of propeller heads here you see... It's very engineering dominated and they tend to not really be that interested in business an awful lot. But also it comes from the fact that they've grown up with a company that's always successful, that's always stable, that always makes its targets. (Director)

The evidence suggests that some so-called knowledge workers find themselves in (and may deliberately seek out) workplaces where they can enjoy applying their expertise, but at the same time find the conditions to sustain the type of work-life balance that becomes more important with age. To this extent, the software engineers of The Company may have much in common with the career aspirations of contract researchers in The University. For the engineers, the sense of being 'top of the class' had been forged early on in life, at school and then again at university. Becoming part of an intelligent, technical community at work was the next natural step. The organization they had joined was managed by people from the same mould, who used their understanding of their own personal identities to develop structures and an over-arching cultural narrative designed 
to attract and retain engineers with a similar outlook. In effect, the technical and social relations of production of The Company appeared to have created collective organizational and personal identities that were generally mutually constituted and reinforcing.

\section{Conclusion}

In this paper we have set out to explore whether the concept of apprenticeship has relevance for knowledge workers, who possess higher level qualifications and who are employed in knowledge intensive organisations. We suggested that despite their levels of qualification on entry to their respective workforces, such workers still engage in an extensive learning journey, which bears at least some of the characteristics of apprenticeship. For the researchers, gaining post-graduate qualifications (and notably the $\mathrm{PhD}$ which itself is based on an apprenticeship model) was an early staging post in their apprenticeship. Along the way, they are also expected to develop a portfolio of achievements including, publications and research roles on different projects. Their salary will be increased through the annual increment pay system within grades, but they will have to apply for progression to the next level. For the software engineers, it is a more straightforward scenario. Once selected, they are expected to learn how to do the job well and in return they will receive an annual reward in their salary through the profit share scheme.

Both the university CRs and software engineers were legitimate peripheral participants. The researchers made their way through, often, a series of post-doctoral positions to the point at which they could gain permanent status associated with secure 
employment, autonomy, discretion over the conception of tasks, the eligibility to lead on research bids and to supervise others. However, the achievement of this status was far from certain as the risks associated with an irregular funding stream are mitigated by the availability of contract staff, whose terms and conditions (even after the implementation of the European Directive) are still less secure than their established colleagues. In Lave and Wenger's terms then, far from being a straightforward movement from legitimate periphery to mainstream, these knowledge workers' trajectories could be characterised as 'treading water' in the sense that they can get stuck in a succession of post-doctoral posts without managing to achieve that all-important transition. Inevitably this experience of 'marginality' (Wenger 1998) led some to rethink their academic and research goals and to look to different sorts of career options.

In contrast, the management and development of novice software engineers was designed to ensure a steady movement from legitimate peripheral to mainstream participant. In this sense their trajectory mapped quite neatly onto an apprenticeship model as teaching and learning were integral to their experience of the work. As we have explained, the key factors in facilitating this process were the integration of 'teaching' into the manager's role, and the structured and scaffolded support for individuals to become managers. For the software engineers then, one indicator of the end of an apprenticeship was certainly met in that they progressed to the stage of a 'teacher' of new novices. With regard to the use in The Company of the teaching role to represent the individual's ability to train and bring on others, there is some similarity with the role of 'meister' in the German Apprenticeship system. 
However, in terms of another 'post-apprenticeship' indicator, discretion over the conception of tasks, the evidence from the software engineering company is less strong, and indicates that 'teaching' and 'discretion' need to be decoupled as they act as different windows onto whether the apprenticeship has come to an end. Although, the software engineers become managers and teachers, this does not mean that they become autonomous in terms of the roles they play in their teams. This is because it is the team leader (a senior manager) who has the responsibility for planning and allocating tasks, evaluating how well these are executed, and liaising with the company directors. The question of how individuals progress to the senior echelons of The Company, and how long this takes, remains. Given the low turnover and the deliberately conservative growth strategy being employed, the opportunities for advancement get progressively more limited towards the top of the organisational tree. Furthermore, while The Company is engaged in developing cutting edge technological products and solutions to clients' needs, the core activity of the business is completing the programming/coding necessary to deliver the relevant projects to specification. Discretion in how this is carried out is likely to be circumscribed from above. In our terms, then, there is a 'restrictive' aspect to The Company's approach to workforce development that may well be necessary in order to 'get the job done' and which may well be the reality of the lived experience in any knowledge intensive organisation.

The approach to teaching and learning at work in The Company differed, therefore, from that in The University, where workplace learning was considered an ad hoc, tacit 
and individual aspect of work. In The University, training was provided to individuals in the form of off-the-job courses that appeared to address individual needs, but which did not form part of an organizational workforce and business development plan. There are, however, interesting parallels between The University and The Company with respect to the aspirations and motivations of the knowledge workers they employed. In both organizations, interviewees wanted to work in intelligent communities, where the quality of the work was of prime importance. In the case of The Company, a sophisticated system of performance review and constructive feedback, together with the conceptualization of management as a key vehicle for the transmission and creation of knowledge and skills among software engineers, had created an environment in which talented individuals could flourish, but only to the extent that they served the needs of the team. The profit share arrangements were clearly a major weapon in The Company's ability to attract and retain staff, whereas The University was more restricted in terms of the reward incentives it could use.

The contrast between the two sets of knowledge workers in terms of their experience of legitimate peripheral status has been insightful as it has indicated that, unlike the software engineers who finish 'their journey', some researchers may never finish as they get locked into a peripheral and marginal status. This is compounded by the employment structure and culture of the research world, which relies on the survival of the fittest and an over-supply of qualified 'troops'. The researcher example also highlights a flaw in the contemporary narrative of the knowledge worker which has ignored the reality that changes in the demand for knowledge workers mean that many, as 
in the case of university researchers, may have to stay in the ranks or disappear through wastage. The rigorous selection process implemented by The Company mitigates this risk by matching its intake with its demand for staff. It was deliberately limiting its growth to retain its specialist niche position, and to ensure that it stayed focused on its core business. The directors felt that a growth strategy would inevitably mean that they had to employ more 'troops' or use sub-contractors. As we have observed, even in a knowledge intensive and generally expansive workplace learning environment such as this, there are, probably inevitably, restrictive aspects in their practice.

In this paper we have argued that drawing on apprenticeship as a model of learning and applying aspects of the expansive restrictive framework to our analysis has helped reveal the differences between the formation experiences of the two sets of knowledge workers. The analysis leads us to suggest that viewing the professional formation of knowledge workers as apprenticeship would encourage organisations to think about the nature and purpose of formation and how it can be supported. The dramatic decline in the global economy in recent months brings an urgency to the need for fresh thinking in this area, particularly in light of the expansion of higher education systems and the number of graduates seeking to enter the labour market as 'knowledge workers'.

\section{References}

Allen-Collinson, J. (2003) 'Working at a marginal 'career': the case of UK social science contract researchers', The Sociological Review, pp. 405-422.

Alvesson, M. (2001) 'Knowledge work, ambiguity, image and identity', Human Relations, 54(7): 863-86. 
Barrett, R (2001) 'Labouring under an illusion? The labour process of software development in the Australian information industry', New Technology, Work and Employment, 16(1): 18-34.

Bell, D. (1973) The Coming of Post-industrial Society, New York: Basic Books

Brint, S (2001) 'Professionals and the "Knowledge Economy": rethinking the Theory of Postindustrial Society', Current Sociology, 49/4, 101-32

Brown, P., Lauder, H. and Ashton, D. (2008) Education, Globalisation and the Knowledge Economy, London: Teaching and Learning Research Programme

Brown, P. and Hesketh, A. (2004) The MisManagement of Talent, Oxford: Oxford University Press

Bryson, C. \& Tulle-Winton, E. (1994) A survey of contract research staff in UK universities, AUT, London.

Committee of Vice-Chancellors and Principals (CVCP), (1996), A Concordat to Provide a Framework for the Career Management of Contract Research Staff in Universities and Colleges, London: CVCP.

Cortada, JW (1998) Rise of the Knowledge Worker, Boston MA:Butterworth-Heinemann

Drucker, P. (1959) Landmarks of Tomorrow: A report on the new 'post-modern' world, New York: Harper and Row

Drucker, P. (1969) The Age of Discontinuity, New York: Harper and Row

Felstead, A., Fuller, A., Jewson, N. and Unwin, L. (2009 in press) Improving Working as Learning, London: Routledge.

Felstead, A., Jewson, N. and Walters S. (2005a) Changing Places of Work, Basingstoke: Palgrave Macmillan.

Fenwick, T. (2004) 'Learning in portfolio work: anchored innovation and mobile identity', Studies in Continuing Education, 26(2): 229-46.

Fox, A. (1974) Beyond Contract: Work, Power and Trust Relations, London: Faber.

Freedman, E., Patrick, H., Somekh, B., McIntyre, D. and Wikeley, F. (2000) Quality conditions for quality research: guidance for good practice in the employment of contract researchers in Education, Southwell: British Educational Research Association. 
Fuller, A. and Unwin, L. (2003) Learning as apprentices in the contemporary UK workplace: creating and managing expansive and restrictive participation, Journal of Education and Work, 16(4): 407-26.

Fuller, A. and Unwin, L. (2004), 'Expansive learning environments: integrating organizational and personal development' in Rainbird, H., Fuller, A. and Munro, A. (eds) Workplace Learning in Context, London: Routledge.

Fuller, A. and Unwin, L. (2008) Towards Expansive Apprenticeships, TLRP: London

Fuller, A., Unwin, L., Felstead, A., Jewson, N. and Kakavelakis, K. (2007) Creating and using knowledge: an analysis of the differentiated nature of workplace learning environments, British Educational Research Journal, 33 (5) 743-759

Guile, D. (2006) What is distinctive about the knowledge economy? Implications for education, in H. Lauder, P. Brown, J.A. Dillabough, and A.H. Halsey, Education, Globalisation and Social Change, Oxford: Oxford University Press

Lave, J. and Wenger, E. (1991) Situated Learning: Legitimate Peripheral Participation, New York: Cambridge University Press.

Livingstone, D. and Sawchuk, P. (2003) Hidden Knowledge: Organised Labour in the Information Age, Aurora, Canada: Garamond Press.

Marks, A. and Lockyer, C. (2005) 'Professional identity in software work', in Barrett, R. (ed.) Management, Labour Process and Software Development, London: Routledge.

Office of Science and Technology (OST) (1998), Research Careers Initiative Report, October 1998, London: OST.

Quintas, P. (1994), Programmes innovation? Trajectories of change in software development, Information Technology and People, 7(1): 25-47.

Reich, R. (1991) The Wealth of Nations, London: Simon and Schuster.

Roberts, Sir Gareth (2002), SET for Success. The supply of people with science, technology, engineering and mathematics skills. The report of Sir Gareth Roberts' Review, London: HM Treasury.

Robinson, H., Hall, P., Hovenden, F., and Rachel, J. (1998) 'Postmodern software development', The Computer Journal, 41,6:363-375.

Scarborough, H, Swan, J, Preston, J (1999), Knowledge Management: A Literature Review, IPD, London. 
Wenger, E. (1998) Communities of Practice: Learning, Meaning and Identity, Cambridge: Cambridge University Press.

Williams, G., Blackstone, T. and Metcalf, D. (1974) The academic labour market, Amsterdam: Elsevier.

Williams, G., Blackstone, T. and Metcalf, D. (1974) The Academic Labour Market, Amsterdam: Elsevier.

Wolf, A. (2002) Does Education Matter? London: Penguin

Unwin, L., Felstead, A., Fuller, A., Bishop, D., Lee, T., Jewson, N. and Butler, P. (2007) Looking inside the Russian doll: the interconnections between context, learning and pedagogy in the workplace', Pedagogy, Culture and Society, 15 (3), 333-348 


\begin{abstract}
Alison Fuller and Lorna Unwin
'KNOWLEDGE WORKERS' AS THE NEW APPRENTICES: THE INFLUENCE OF ORGANISATIONAL AUTONOMY, GOALS AND VALUES ON THE NURTURING OF EXPERTISE
\end{abstract}

\author{
Alison Fuller \\ Professor of Education and Work \\ School of Education \\ University of Southampton \\ Highfield Campus \\ Southampton \\ SO17 1BJ \\ Email: a.fuller@soton.ac.uk \\ Tel: 02380598864 \\ Fax: 02380593556 \\ Lorna Unwin \\ Professor of Vocational Education \\ Department of Lifelong and Comparative Education \\ Institute of Education University of London \\ 20 Bedford Way \\ London \\ WC1H 0AL
}


Alison Fuller is Professor of Education and Work and Head of the Lifelong and Work-related Learning Research Centre in the School of Education, University of Southampton. Her research interests include apprenticeship, workplace learning, changing patterns of participation in Further and Higher education, and education work transitions through the lifecourse. Alison was Special Adviser to the UK Parliament's House of Commons Select Committee on Innovation, Universities, Skills and Science's Scrutiny of the current Apprenticeship Bill. Her most recent book, co-authored with Alan Felstead, Lorna Unwin and Nick Jewson) Improving Working as Learning has been published by Routledge (2009). 
Lorna Unwin is Professor of Vocational Education and Deputy Director of the ESRCfunded Centre for Learning and Life Chances in Knowledge Economies and Societies (LLAKES) at the Institute of Education, University of London. She was previously the Director of the Centre for Labour Market Studies at the University of Leicester and has held academic posts at the Open University and University of Sheffield. Her key research interests include workplace learning, vocational education and economic change, and apprenticeship. Her recent books include Communities of Practice: Critical Perspectives (2007) and Improving Working as Learning (2009) both published by Routledge 